\title{
Genealogy and Geology: Of Metanarratives of Origins
}

\section{Héliane Ventura}

\section{(2) OpenEdition \\ 1 Journals}

Electronic version

URL: https://journals.openedition.org/ces/7887

DOI: $10.4000 /$ ces.7887

ISSN: 2534-6695

Publisher

SEPC (Société d'études des pays du Commonwealth)

\section{Printed version}

Date of publication: 1 September 2011

Number of pages: 93-100

ISSN: 2270-0633

\section{Electronic reference}

Héliane Ventura, "Genealogy and Geology: Of Metanarratives of Origins", Commonwealth Essays and Studies [Online], 34.1 | 2011, Online since 16 November 2021, connection on 01 December 2021. URL: http://journals.openedition.org/ces/7887 ; DOI: https://doi.org/10.4000/ces.7887

\section{(c) (i) $\odot$}

Commonwealth Essays and Studies is licensed under a Licence Creative Commons Attribution - Pas d'Utilisation Commerciale - Pas de Modification 4.0 International. 


\section{Genealogy and Geology: Of Metanarratives of Origins}

This essay addresses the theme chosen for the issue, "Tectonic Shifts," in geological terms and contemplates the individual micro-histories that are narrated in emergent fictions against the larger scenarios of geo-dynamic mechanisms that have created the contours of the contemporary world. It engages in the preoccupation with origins in postcolonial writing from a point of view which is successively panoramic (Andrea Levy, Bernardine Everisto, Anita Desai, Kathy Page, Joan Thomas) and closely focused (Alice Munro, Dance of the Happy Shades and The View from Castle Rock). It provides evidence of the contemporary updating of the modes of story-telling through the synchronization of the historical novel, epic poetry and autobiography in stories which develop a parallel quest for geology and genealogy.

The theme chosen for this issue, "Tectonic Shifts," encourages us to envisage the development of postcolonial literature in geological terms. It invites us to address the individual micro-histories that are narrated in emergent fictions against the larger scenarios of geo-dynamic mechanisms that have created the contours of the contemporary world. Thus it ambitiously leads us to set human temporality against a geological time-frame, to set human action against techtono-physics or, even more resolutely, to set the birth of man against the opening of oceans. The extensive scope of the investigation reconfigures the role of territorial affiliation in the literary creative process. As it aggrandizes the focus and enlarges the investigation to accommodate a preoccupation with the formation and breakup of continents, the geological perspective simultaneously renders possible a post-national discussion and a retrospective consideration of origins. The preoccupation with origins is an outstanding feature of postcolonial literatures which has been repeatedly stressed. Salman Rushdie, for instance, has underlined the unavoidable sense of loss and nostalgia that underpins migrant or diasporic literature. ' Instead of conducting an analysis of these paradoxically paralyzing and empowering emotional drives, this essay addresses the preoccupation with origins in postcolonial writing from a point of view which is successively panoramic and closely focused as well as inspired by the three characteristics that Deleuze and Guattari have attributed to minor literatures: deterritorialized, collective and political (33).

To provide a backdrop to a more focused discussion of Alice Munro's 2006 collection of stories, The View from Castle Rock, I would like to begin with a selection of examples which are particularly remarkable for their transatlantic techtono-dynamism while including the criteria of collective and political deterritorialization. First, two novels emanating from two female British writers: Andrea Levy's Fruit of the Lemon (1999) and Bernardine Evaristo's Lara (2009). They are both semi-autobiographical novels in which the main protagonists, respectively Faith and Lara, travel back in time and space as if to search for their lost origins but also to reach out for the history of a

1. Rushdie has noted this tendency of the migrant, the exile, the emigrant "to be haunted by some sense of loss, some urge to reclaim, to look back, even at the risk of being mutated into pillars of salt" (10). 
people. Faith, who was born in England and has never known the West Indies, literally draws up a genealogical chart, which is graphically included in the volume, before actually leaving England to get acquainted and affiliate herself with her Caribbean family, while Lara, born in London to an English mother and a Nigerian father, travels from London to Lagos and to Brazil in order to explore her family history which is also a collective history of oppression and victimization, of displacement and abjection. From Europe and Africa to North and South America, both novels operate a temporal and spatial extension and compression which give rise to collisions and lead back to the original displacement caused by the slave trade. The contemporary transatlantic journey is necessarily polyphonic and polytropic: it simultaneously reactivates the pressure and oppression of origins, the geophysical pressure of the lithosphere upon the asthenosphere on the geological level (upon which the theory of plate tectonics is based) and the oppression of racial subjugation on the anthropological level.

With less seismic intensity but more spatial extension, wider seafloor spreading can also be brought to the fore. For instance, Journey to Ithaca (1995), by Anita Desai, documents the real journeys from Italy and Germany to India and Egypt that the protagonists undertake, highlighting the collisions, the frictions and the overlapping that such spreading over wide chasms entails. In addition to real journeys, this novel operates a symbolic collision suggested by its Homeric title. It concentrates on the spiritual quest of a young hippie couple, Sophie and Matteo, who first leave Italy together to travel to India before embarking separately on a re-versioned nostos or individual return journey to Italy in the end. Sophie does not return home to her own German origins, but retraces the steps of the spiritual leader her husband has apparently dedicated his life to, the Mother, whose teachings drew a great number of followers. Her convoluted journey, which takes her to Egypt, is not one of reverence but rather of re-mastery or symbolic re-legitimizing, while Matteo's eventual return to Italy, and to Sophie, suggests a potential opening of new zones of accretion, of subduction and transformation.

The widest amplitude yet is to be attributed to two Canadian novels which provide the maximal temporal extension. Both are concerned with paleontology and highlight a geological concern for the digging out of fossils. In other words, the preoccupation with origins in these novels moves the focus from history to pre-history. The first novel, The Find by Kathy Page, published in 2010, revolves around the discovery of a pterosaur in the native community of Big Crow in British Columbia, as well as the coextensive unearthing of some of the protagonists' hidden motives and fears. The second novel, by Joan Thomas, also published in 2010, is entitled Curiosity and documents the life of a historical 19 ${ }^{\text {th }}$-century figure, a cabinet-maker's daughter called Mary Anning who discovered in the cliffs of Lyme Regis in Dorset the first intact skeleton of a prehistoric creature. She thus became perhaps the most important paleontologist of her day, forty years before the publication of the Origin of Species, although she was unrecognized by the male-dominated, class-ridden scientific community.

The concern with geology in Canadian literature is not restricted to these two most recently published novels. As demonstrated by Nina van Gessel in "Autogeology: Limestone and Life Narrative in Carol Shields's The Stone Diaries [1993]," Daisy 
Goodwill's life story evidences a structural analogy between limestone and autobiography through the similarity between their respective patterns of accretion and erosion, of information and obfuscation. As highlighted by Claire Omhovère in Sensing Space: The Poetics of Geography in Contemporary English-Canadian Writing, Thomas Wharton's first novel, Icefields (1995), also relies on glacial dynamics to orchestrate its plural narratives. An earlier novel, Badlands by Robert Kroetsch (1975), already displayed a remarkable preoccupation with geology which assumed a dual characteristic, as the geological quest was paralleled with a genealogical one. Although examples of the parallel concern for geology and genealogy in Canadian literature abound, ${ }^{2}$ it would be a sweeping generalization to posit the exceptionality of Canadian literary production, for a number of other postcolonial novels or poems do intertwine these two concerns. Suffice it to mention Eleni Sikelianos, the Greek-American poet, who negotiates the epic tradition by mixing genealogy, geography and geology. The present essay limits the claim to Alice Munro, whose interest in geology and genealogy is an outstanding feature of her works that has been seldom commented on and which is part and parcel of a postcolonial return to origins which overrides history to reach back towards a universal common ground rooted in prehistory.

Munro demonstrates her tropism from the very first story, "Walker Brother Cowboy," in her first collection, Dance of the Happy Shades (1968), in which her interest in the geological formation of contemporary landscape looms particularly large. This is the description of Lake Huron that the father gives to the young protagonist:

He tells me how the Great Lakes came to be. All where Lake Huron is now, he says, used to be flat land, a wide flat plain. Then came the ice, creeping down from the north, pushing deep into the low places. [...] And then the ice went back, shrank back towards the North Pole where it came from and left its fingers of ice in the deep places it had gouged, and ice turned to lakes and there they were today. (3)

In The View from Castle Rock, published almost forty years later in 2006, Munro reiterates the description of the formation of the Great Lakes: "The landscape here is a record of ancient events. It was formed by the advancing, stationary and retreating ice. The ice has staged its conquests and retreats several times, withdrawing for the last time about fifteen thousand years ago" (318).

I propose to examine closely the different tropings given by Munro to the description of the formation of the Great Lakes. In "Walker Brother Cowboy," the outstanding trope is that of the fingers of ice, while in The View from Castle Rock the trope is military, as glacial dynamism is likened to a series of conquests and retreats. In both cases the landscape is submitted to a process of anthropomorphic description which is nevertheless widely dissimilar. The fingers of ice which gouge the rocky plains in "Walker Brother Cowboy" do not belong to mortal man: they are less anthropomorphic than theriomorphic, evoking the presence of an animal. They connote the intervention of a superhuman agency such as the Wendigo. As Margaret Atwood points out, " $[\mathrm{n}$ their indigenous versions, Wendigo legends and stories are confined to the eastern woodlands, and largely to Algonquian-speaking peoples such as the Woodland Cree and the Ojibway" (66). But this native legend has infiltrated non-native literature and widely cross-pollinated over and beyond its original 
boundaries. In the words of Atwood, "the Wendigo is - among other things - a giant spirit-creature with a heart and sometimes an entire body of ice, and prodigious strength; it can travel as fast as the wind" (66). It is also cannibalistic, eating preferably the members of the same family, and it is generally seen as "a personification of winter, or hunger, or spiritual selfishness" (67). By using the metaphor of fingers of ice of prodigious strength, Munro allusively and discreetly underpins the geological with the mythological.

As she bolsters the scientific with the fabulous, she performs a complex act based upon hybridizing mythologies and re-legitimizing metanarratives. On the ceiling of the Sistine Chapel in Rome is one of the most famous icons in the Western world: the representation of God imparting life to Adam through the outstretched finger of his right arm. This major iconic moment in Western art is figured at least twice in Munro's works. In "Goodness and Mercy" from her 1990 volume Friend of My Youth, the life-giving dimension of the outstretched finger is reversed into its opposite as the dying protagonist embarks on her final passage and waves goodbye "to the disappearing land, a dark blue-finger of Labrador" (156). In "Walker Brother Cowboy," the finger of ice melting into a lake generates the advent of living species on the surface of planet earth; Munro here creates her own cosmogony, her eschatological metanarrative of origins in which she allows the native Ojibway and Woodland Cree legend to mix with the Christian, Renaissance vision of the creation of Man.

Her 2006 collection of stories, The View from Castle Rock, is marked by an even more pronounced transatlantic techtono-dynamic, since in this special set of stories, she retraces the journey of her father's Scottish ancestors in the opposite direction. In the first part of the volume Munro conducts an extensive genealogical quest, a journey of reclamation in which she methodically traces her patrilineal descent from her father Robert Laidlaw born in Western Ontario in the early years of the $20^{\text {th }}$ century to her great-great-great-grandfather, James Laidlaw, who left Scotland to set sail for Canada in 1818, and to her distant cousin James Hogg, the peasant poet (also called the Ettrick Shepherd) who gained enduring fame with the publication of the Private Memoirs and Confessions of a Justified Sinner in 1824.

I would like to envisage this journey of reclamation which leads her to Europe in the light of the military metaphor that she uses to describe Canadian glacial movements in "What Do You Want to Know For?" the last story in The View from Castle Rock. With its passage to Scotland and its return to Western Ontario in the end, the entire volume is formed by the advancing, stationary and retreating course of the main protagonist: the self-declared author herself who, in the later part of her life, after dedicating most of her writing career to self-examination, actually and literally turned to the bedrock of her family - a castle perched upon an extinct volcano, in the center of Edinburgh. This movement there and back, which is also a movement to and fro, since she has been to Scotland at least twice, engaging each time in some kind of reclamation, has a defiant, transgressive quality. It is spurred by a desire for knowledge, by Munro's insatiable curiosity about her forefathers, by her “epistemophilic impulse," to use Melanie Klein's formula (203). Munro de-legitimizes the Calvinist distrust for speculative activities which she stigmatizes in the title of the last story, "What Do You Want to Know For?" and she re-legitimizes the acquisition 
of knowledge by lending value to intellectual curiosity, whether it is applied to genealogy or geology. After investigating thoroughly her family history in Scotland and charting her genealogy, she returns to Western Ontario to scrutinize geological maps:

Look at just one map - a section of southern Ontario south of Georgian Bay. Roads. Towns and rivers appear as well as township boundaries. But look what else - patches of bright yellow, fresh green, battleship gray, and a darker mud gray, and a very pale gray, and splotches or stretches or fat or skinny tails of blue and tan and orange and rosy pink and purple and burgundy brown. Clusters of freckles. Ribbons of green like grass snakes. Narrow fluttery strokes from a red pen. (View 319)

Munro endows the description of "the physiography of Western Ontario" with striking predicates. The freckles are said to look like "partly buried eggs" and miniature mountain ranges like "dragon's backs." With this metaphoric reconfiguration of the landscape through the mediation of animal imagery, Munro returns to a landscape of origins, inhabited by saurians and dinosaurs, and she inscribes anthropomorphic family relationships between the elements which compose the landscape. "Mild-mannered creeks" are said to be "descendants" from battering rivers, and "interrupted lines" the remnants of abandoned beaches of the "ancestors" of the Great Lakes (319-20).

Empowered through the knowledge of her own descent, Munro creates an anthropomorphic earth and a natural body. She grounds her cartography of South Western Ontario in the self. She applies the knowledge of her genealogy charted over the Atlantic to the geology of her native land. She superimposes the spatial extension of her family's migration onto the temporal development of the formation of landscape, and she telescopes them to erase the difference between landscape and the human body. To borrow from Peter Brooks' terminology, she performs a double operation which is at the same time a "somatization of the land" and a "semantization of the body" (25). She inscribes the map of the land with blood and leaves painterly and scriptural marks on the body of the landscape. The transformation of the text into an alluvial deposit is paralleled by a transformation of the landscape into a text generated by "narrow fluttery strokes from a red pen." This chiastic exchange enables Munro to return to a geological matrix of origins which is at the same time a living stone, a painterly script, and a storied body.

By returning to her native bedrock and by contemplating it as a matrix of origins, Munro recycles one of the major tropes in Western literature, the one which is found in the Bible with Christ's injunction to Peter to found the church upon a rock. ${ }^{3}$ Munro transgressively revitalizes this metaphor by using her maiden passage to Scotland and Castle Rock, which is also called the Maiden Rock, as the seat of the dissemination of literature through a woman's body. She revisits Castle Rock to reclaim the rock above the Great Lakes, and from this stone matrix she develops stories which dramatize the fecundity of the transmission of literature. By superimposing the genealogical upon the geological in her last but one volume of short stories, Munro bequeaths a sedimentary textual body, an alluvial formation, which points in the direction of the continuance of story-telling beyond the limits of human experience.

3. I am indebted to Chantal Zabus for making this suggestion during the discussion which followed my reading of a shorter version of this essay at the SAES conference in Paris in May 2011. 
By resorting to the geological and genealogical trope, Munro also performs a very personal and poignant operation. In this last story before the epilogue, she reveals the presence of a possibly cancerous tumor in her body, and the military metaphor may serve as a reminder of the battle that she is fighting against the onslaught of a potentially lethal disease. Thus, the military metaphor used to describe glacial dynamics operates on several "plates" at the same time and remains profoundly ambivalent. Like the ice staging its conquests and retreats several times, Munro has been staging her story repeatedly, writing thirteen volumes of short stories which are mostly autobiographic and mostly cover the same ground from 1968 to 2009. From one bedrock to another, she has reconfigured her individual experience by resorting to a geological paradigm, which simultaneously embodies and depersonalizes her trajectory. Beyond her individual life story, and her own fight against cancer, the use of the geological paradigm has enabled her to broaden the scope of her reclamation of the past and to claim its universal dimension. As evidenced by the title of her 1971 collection, Lives of Girls and Women, she aims at staging the march of girls and women through the ages and enacting the counter-narratives of women's lives from time immemorial.

It might be argued furthermore that the stories she has been staging are "white stories" and that the military metaphor serves as a reminder of the fact of colonial settlement and its enactment of power over the First Nations. Through the advance and retreat of glaciation, Munro is metaphorically encapsulating the advance and retreat of Empire, as well as her own passage to Scotland and her own biological defense mechanisms: she synchronizes the geological, the historical, the biological and the personal in an extensive equation between man's dis-location and the large-scale motions of the earth's lithosphere. ${ }^{4}$

Munro's volume of short stories displays an embodied topography which is at the same time an itinerary of self-discovery as geology. The metonymic figuration of the matrix of origins from which her life and her stories developed occurs in the last paragraph of the epilogue to the volume of 2006 in which she conjures up a seashell as the last object from the past that she has been reclaiming:

And in one of these houses - I can't remember whose - a magic door stop, a big mother-of-pearl seashell that I recognized as a messenger from near and far, because I could hold it to my ear - when nobody was there to stop me - and discover the tremendous pounding of my own blood and the sea. (View 349)

This single final line of the volume is at once a noun phrase and a hypotactic sentence which conjoins opposites: it features a door stop in order to keep the door ajar, it evokes closure to foster aperture, it suggests proximity to make room for distance, it conjures up the mineral to evoke fluidity and it brings life out of stone only to dissolve the individual into an oceanic flux. In her conclusion to this special set of stories, with the conjuring up of the seashell, Munro proffers a key image which is also an intertextual and interpictorial reference. In Golding's Lord of the Flies, a sea conch is used as an emblem of democracy and a preserver of civilization on the island on

4. I am indebted here to Katie Trumpener's analysis of Samuel Johnson's Journey to the Western Islands of Scotland (1775) in which she highlights the equation between Scotland's tripartite geological formation with the movements across several kinds of Enlightenment conceptual terrain (69). 
which the teenagers are stranded. That Munro should finish a volume entitled The View from Castle Rock on the image of a preserved seashell is particularly significant, given that in Golding's novel the decay of civilization and the rise of tyranny are symbolised by the shattering of the sea conch and the settlement of the tribe in the part of the island called Castle Rock. Munro's re-appropriation of the historical Castle Rock for the title to the collection and her finishing on the sound from the intact seashell as an oceanic messenger perform a metonymic reclamation of the past which is re-generative.

These intertextual allusions are possibly supplemented with an interpictorial reference. In the Musée d'Orsay there is a painting by Odilon Redon entitled The Seashell (1912) which might very well be considered the hypo-icon to which Munro is indirectly alluding. She has repeatedly stated that her stories developed from a clear design. ${ }^{5}$ Her present volume finishes with a picture of origins, the origins of the world in a seashell, which is a metonym for the womb, sea-changed into mother-of-pearl. It is only one of the large- and small-scale ironic reversals of Munro's writing that a volume dedicated to the paternal side of her family should conclude with an explicit homage to the maternal function of generation. With the picture of the seashell Munro produces and reproduces a metanarrative of origins which is also a sequence of self-re-engendering and re-engendering of stories. With her parallel quest for geology and genealogy, she synchronizes the historical novel, epic poetry and autobiography in her short stories. From the rock of her ancestors which she revisited at least twice over the sea, to the Great Lakes on the North American continent, she undertakes a journey of self-reclamation over vast distances and several centuries to situate her stories in the continuum of human life and artistic production. Her updating of the modes of story-telling is as momentous as the comparison she draws between the templates of human collision and the lithospheric plates riding on the asthenosphere, and through her minor stories, repeatedly autobiographic and relentlessly self-centered, she makes us glimpse eternity in mother-of-pearl

Héliane VENTURA, Université de Toulouse - le-Mirail

\section{Works Cited}

ATWOOD, Margaret. Strange Things: The Malevolent North in Canadian Literature. Oxford: Clarendon, 1995.

BRoOKS, Peter. Body Work: Objects of Desire in Modern Narrative. Cambridge, MA: Harvard UP, 1993.

Deleuze, Gilles, and Félix GuATTARI. Kafka: Pour une littérature mineure. Paris: Minuit, 1975.

DESAI, Anita. Journey to Ithaca. London: Vintage, 1995.

EvARISTO, Bernardine. Lara. London: Bloodaxe, 2009.

KLEIN, Melanie. "Early Stages of the Oedipal Conflict." Contribution to Psycho-Analysis, 1921-1945. London: Hogarth, 1950. 202-26.

LEVY, Andrea. Fruit of the Lemon. London: Headline, 2000.

MunRo, Alice. Dance of the Happy Shades. Toronto: McGraw-Hill Ryerson, 1968.

—. Friend of My Youth. London: Vintage, 1990.

—. The View from Castle Rock. Toronto: McGraw-Hill Ryerson, 2006.

Omhovère, Claire. Sensing Space: The Poetics of Geography in Contemporary English-Canadian Writing. Bruxelles: PIE Peter Lang, 2007.

Page, Kathy. The Find. Toronto: McArthur, 2010.

5. In an interview with Alan Twigg she said: "It's as if I must take great care over everything. Instead of splashing the colours out and trusting they will all come together, I have to know the design" (Twigg 16). 
Redon, Odilon. La Coquille: en bas à droite petit coquillage, dans l'ombre. 1912. Pastel 52 x 57,8. Musée d'Orsay, Paris.

RusHDIE, Salman. Imaginary Homelands: Essays and Criticism 1981-1991. London: Penguin, 1991.

THOMAS, Joan. Curiosity. Toronto: McClelland \& Stewart, 2010.

Trumpener, Katie. Bardic Nationalism: The Romantic Novel and the British Empire. Princeton: Princeton UP, 1997.

TwigG, Alan. For Openers Conversations with 24 Canadian Writers. Madeira Park, BC: Harbour, 1991.

VAN GeSSEL, Nina. "Autogeology: Limestone and Life Narrative in Carol Shields's The Stone Diaries." History, Literature, and the Writing of the Canadian Prairies. Ed. Alison Calder and Robert Wardaugh. Winnipeg: U of Manitoba P, 2005. 63-85. 